\title{
Burden, profile and care: caregivers of socially vulnerable elderly persons
}

Isabela Thaís Machado de Jesus' Ariene Angelini dos Santos Orlandi ${ }^{2}$ Marisa Silvana Zazzetta²

\section{Abstract}

Objectives: To compare burden and sociodemographic profile and to analyze the care needs of caregivers of elderly persons enrolled in Social Care Referral Centers in a municipal region in the interior of the state of São Paulo, Brazil. Method: A cross-sectional, quantitative-qualitative study was carried out. A sociodemographic questionnaire, the Zarit Burden Scale and three open questions regarding care needs were applied. The quantitative data were analyzed by descriptive statistics and the correlation test. The hermeneutic-dialectic referential was applied and the qualitative data were analyzed by the content analysis technique. Results: A total of 86 caregivers participated in the study. The majority were female $(71.7 \%)$, had a mean age of 56.5 ( $\mathrm{sd}=14.9)$ years, suffered burden and lived in vulnerable neighborhoods. With regard to care, the provision of support for activities of daily living, difficulties in caring and the help of other relatives were identified. Burden negatively correlated with age range and schooling $(r=-0.11$; $\mathrm{r}=-0.87$ ). Conclusion: Guidance and the acquisition of caring skills remain unprovided by the resources and services that exist in vulnerable contexts, and resolutive support strategies are lacking in public facilities.

\footnotetext{
Universidade Federal de São Carlos, Centro de Ciências Biológicas e da Saúde, Departamento de Enfermagem, Programa de Pós-graduação em Enfermagem. São Carlos, São Paulo, Brasil.

2 Universidade Federal de São Carlos, Centro de Ciências Biológicas e da Saúde, Departamento de Gerontologia. São Carlos, São Paulo, Brasil.

Research funding: Coordination of Improvement of Higher Level Personnel (Capes). Master's Degree Scholarship.

Keyword: Caregiver, Family. Social Vulnerability. Elderly. 


\section{INTRODUCTION}

Increased life expectancy affects the health conditions, morbidity and functional limitations of the elderly, increasing the incidence of illnesses and disabilities, with possible alterations in physical, cognitive and emotional dependence, generating a need for permanent care ${ }^{1}$. Whether physical or cognitive in nature, dependence means that the elderly require dedicated care to meet their specific needs ${ }^{2}$.

Caregivers of elderly persons are those who assume responsibility for care, offering support and assistance to individuals in need. An "informal caregiver" is defined as a person who provides unpaid care while a "formal caregiver" is someone with professional preparation and training. ${ }^{3}$. Family caregivers assume this role through the initiative or denomination of the family group, according to three factors: kinship, gender and physical and affective proximity. A family caregiver is defined as a person responsible for the care of the elderly, who receives no remuneration and who has cared for the patient for at least three months, for a minimum of four hours a day and at least three times a week ${ }^{4}$.

Throughout the care of the elderly, many informal caregivers experience restrictions in their personal lives due to assuming the responsibility of caring and performing tasks in an uninterrupted manner. They can face situations of attrition, resulting in the loss of affective and professional relationships and limitations in social networks of conviviality and leisure, which can lead to burden ${ }^{5}$. Burden can influence the development of psychiatric, physical, emotional and social symptoms and medication use. In addition, caring can affect the financial situation of the caregiver and compromise the quality of care offered ${ }^{6}$.

Level of burden is directly related to the degree of dependence of the elderly person? ${ }^{7}$. Literature shows that the home represents a privileged space for care, characterized by concern for the integrality and uniqueness of the human being, the valorization of relationships and respect for others, with the family participating in and providing the necessary support ${ }^{8}$. In this context, however, there are concerns over the scarcity of support services. Family members, as the source of support, use their own efforts and resources to provide care and, in many cases, have demands placed on them that represent a burden?.

In a context of social vulnerability, the quality of care is characterized by social and economic aspects and can be a synonym for social risk, frailty and precariousness. Schooling, as an indicator of vulnerability, can limit social and economic mobility, as well as affecting levels of productivity and income, which can hamper the ability of caregivers to acquire information and perform everyday tasks, as the act of caring involves the fulfilment of medical prescriptions, the administration of medication, professional guidance and the seeking of resources in the public system ${ }^{10}$.

There are still gaps in scientific literature in terms of studies that investigate the burden of caregivers in situations of social vulnerability. A study carried out with 140 elderly caregivers in Manguinhos (Rio de Janeiro), characterized as a region of extreme socio-environmental vulnerability, found that $41.6 \%$ of caregivers suffered burden ${ }^{11}$. Thus, primary care services in the public health and social protection systems must use this knowledge to promote interventions that address the specific needs of caregivers in a context of social vulnerability, as social characteristics affect health, generating adverse exposures and risks.

The present study aimed to compare burden and sociodemographic profile and to analyze the care needs of caregivers of elderly persons enrolled in Social Care Referral Centers (SCRC) in a municipal region in the São Paulo countryside. We therefore sought to interpret the contradictions that emerge in the act of caring from the discourse of the caregivers.

\section{METHOD}

A descriptive, cross-sectional study with a quantitative-qualitative approach was carried out. The interviews were carried out with 86 elderly caregivers enrolled in five SCRC in the municipality of São Carlos, São Paulo, Brazil.

The inclusion criterion for participation in the study was to be a caregiver of an elderly person registered at the SCRC, whether a family member or 
not. For the identification of social vulnerability, the São Paulo Social Vulnerability Index was used, which classifies census tracts according to socioeconomic and demographic dimensions, with the former covering the schooling and the income of the head of household and the latter including the age of the head of household and the presence of children aged up to four years in the home. The classification of social vulnerability is divided into six groups: no vulnerability, very low, low, medium, high and very high vulnerability ${ }^{12}$.

The municipal region of São Carlos, which has a population of 221,950 inhabitants, is served by five SCRC distributed in regions of low, very low and high vulnerability ${ }^{13}$. The five SCRC were identified as I, II, III, IV and V. SCRC I, II and III were located in regions with high vulnerability, SCRC IV in a region of low vulnerability and SCRC $\mathrm{V}$ in a very low vulnerability area ${ }^{12}$.

Data was collected by accessing all the existing medical records available and selecting those which related to elderly persons, giving a total of 1,451 records. After identifying the name, age and address of such persons, an active search was performed and 1,118 individuals were excluded as follows: $679(46.7 \%)$ were not found in the aforementioned registered addresses or had changed their address or resided in areas outside the SCRC, and 439 (57.0\%) representing losses due to refusal to participate, death, withdrawal or the fact that the elderly persons lived alone and could not understand or answer the questions. It was decided not to perform a sample calculation and to perform an active search with all the elderly that were registered in the system. Of the 333 elderly persons who were eligible, 86 had caregivers.

The interviews were conducted from Monday to Friday, during working hours, from August 2012 to August 2016. The average duration of each interview was 45 minutes. The interview was carried out by students of the undergraduate course in Gerontology of the Universidade Federal de São Carlos (UFSCar), who were previously trained to standardize the data collected.

Data collection involved instruments for sociodemographic characterization previously constructed by the researchers, the Zarit Burden
Scale and three open questions regarding the needs of care, also developed by the researchers.

The sociodemographic instrument involved questions relating to: gender; age; marital status; schooling; current occupation; income; form of obtaining income and degree of kinship with the elderly. The Zarit Burden Scale developed by Zarit et al. in 1980 and translated and validated for Brazil by Scazufca in 2002 was used to evaluate caregiver burden ${ }^{14}$. The scale has 22 multiple choice questions and answers can vary from 0 to 88 points, with the higher the score the greater the burden. As such, 61 to 88 points correspond to severe burden; 41 to 60 points moderate to severe burden; 21 to 40 indicate mild to moderate burden and less than 21 points no or minimal burden. The open questions related to care needs were: "describe the care activities you perform for the elderly"; "what are the main difficulties and/or limitations that you find when providing care?"; "does anyone else assist with care?" For the interpretative reading of the open questions, the "hermeneuticdialectical" methodological approach was used, with the aim of interpreting the existence of conflicts, tensions and contradictions in the act of caring ${ }^{15}$.

Data were analyzed in a descriptive and univariate manner. The numerical variables were explored by the descriptive measures of centrality (mean, median) and dispersion (minimum, maximum and standard deviation). Categorical variables were explored by absolute and percentage simple frequencies. The correlation of burden with the numerical variables was analyzed according to Spearman's correlation coefficient. The Zarit Burden Scale used in the present study obtained a Cronbach's alpha score of 0.85 indicating satisfactory reliability, and a value approximate to that of Scazufca (0.8714). A $p$-value of $<0.05$ was adopted.

The qualitative analysis was performed based on Bardin content analysis. This approach has its origins in the field of social investigations and refers to techniques that allow the making of replicable and valid inferences about the data of a given context and an encrypted interpretation of the material to be obtained. It is understood as the search for meaning or meanings in a document. Bardin ${ }^{16}$ describes content analysis as a set of communication analysis techniques that use systematic procedures and objectives to describe the content of indicator 
messages - whether quantitative or not - that allow the inference of knowledge regarding the conditions of production of these messages ${ }^{16}$. The preexploration of the material was performed in the first phase, analyzing all the responses of the participants regarding care. Subsequently, the significant units for analysis were selected. Explicit words and phrases in the answers were identified. In the third and last phase, the thematic units were categorized, or in other words, classified and regrouped by theme, according to the degree of intimacy or proximity.

The ethical precepts of Resolution 466/12 of the National Health Council were followed. The present study used and broadened the database of the study entitled: "The Frailty of the Elderly and the Basic Social Care System" approved by the UFSCar Research Ethics Committee, approval number: 72182 in 14/08/12, CAAE: 00867312.8.0000.5504. At the time of starting the present study, this database included data from the elderly and caregivers of SCRC I, II and V. The present study included data from SCRC III and IV, approved by the UFSCar Ethics Research Committee, approval n 1785874 on 21/10/16, CAAE: 57857016.0.0000.5504. The aforementioned database includes the data of 247 elderly persons and 86 caregivers, and only data from the caregivers was used.

\section{RESULTS}

Of the 86 elderly caregivers interviewed in this study, $71.7 \%$ were female. The mean age of the caregivers was 56.5 (+14.9) years. Regarding marital status, $65.1 \%$ of the interviewees had partners, while the most prevalent level of schooling was 1 to 4 years. In relation to current occupation, $61.6 \%$ reported working at home, while $33.7 \%$ worked or had a parttime occupation such as: domestic worker/cleaner (11.6\%); general assistant (5.8\%); rural worker (2.3\%); bricklayer $(2.3 \%)$; kitchen assistant $(2.3 \%)$; seamstress (2.3\%); production assistant (2.3\%); waitress (1.1\%); mechanic (1.1\%); salesperson (1.1\%) and hairdresser $(1.1 \%)$. In terms of income, $54.2 \%$ had an income lower than the minimum wage $(\mathrm{R} \$ 880)$ in the form of a public or private pension. In relation to the degree of kinship with the elderly, $40.7 \%$ of caregivers were spouses, while 39.5\% were daughters. As for the vulnerability of the neighborhood where the caretakers lived, 43.1\% lived in neighborhoods with very low vulnerability.

A total of $67.4 \%$ of the interviewees exhibited burden, with $43.1 \%$ suffering mild to moderate burden, 19.7\% moderate to severe burden and 4.6\% severe burden. Female caregivers, aged between 60 and 69 years, with partners, low levels of schooling, who worked at home and did not declare their income, were identified as burdened and lived in vulnerable regions.

Regarding care needs, the analysis of content revealed the following units of analysis: care activities performed for the elderly; difficulties and/or limitations encountered in care and the assistance of another person in providing care.

\section{Activities of care provided for the elderly person}

The activities reported were grouped into the thematic categories Basic Activities of Daily Living (BADL) and Instrumental Activities of Daily Living (IADL). The main BADL and IADL activities reported by the caregivers were: food preparation $(60.4 \%)$; housework (51.1\%); accompanying the elderly to the doctor (51.1\%); bathing (39.5\%); seeking, purchasing and administering medications (36.0\%); managing money (18.6\%); receiving public or private pension (17.4\%) and diaper changing $(17.4 \%)$. Some caregivers performed activities that could contribute to an improvement in the elderly person, such as leisure activities $(3.48 \%)$; exercise for the legs $(2.3 \%)$; going out in a wheelchair (2.3\%); $(2.3 \%)$ and sunbathing $(2.3 \%)$, according to the reports of the caregivers:

"I give him a bath, I shave him, I change his diaper, I prepare the food and I feed him ... I give him medicines, I move him from the bed to the wheelchair and I take him out to get some sun" (C2).

"I help with bathing, I prepare meals, I take them to the doctor and I give them medication" (C6).

"I give them a bath, I make food, I clean the house, I collect the pension and I iron clothes" (C37).

"I tidy the house, get medicines and collect the pension" (C43). 
Difficulties and/or limitations found in care

Of the interviewees, $55.8 \%$ of caregivers reported experiencing difficulties when providing care. In this unit of analysis two thematic categories appeared. One described the difficulties and limitations related to the Objective Dimension of Care, in which the responses of the caregivers described difficulties when providing care, such as physical exertion $(20.9 \%)$ in the transference of the elderly, when bathing and when changing diapers, as described below:

"difficulties when moving him as he's bedridden, he's very heavy" (C8).

“they can't move any of their limbs” (C33).

Other limitations identified were "caregiver health problems" such as prolapsed bladder, labyrinthitis and orthopedic deformities that generated pain and discomfort in the execution of care. Another thematic category was the Subjective Dimension of Care, in which the emotional burden of care and its difficulties were reported by the caregivers, such as: "emotional disturbance" (9.3\%) and the difficulty of having "no social life" (9.3\%). The following sections reveal the difficulties encountered by caregivers:
"I have to beg him to eat... he wakes me up in the middle of the night to take medicine" (C16).

"I get really stressed, it's not easy... they keep asking the same things" (C27).

"I can't take it anymore, it's like looking after a child" (C29).

\section{Help from other people in care}

Of the participants interviewed, 55.8\% reported that they received help from another person and $44.1 \%$ said they did not. In this unit of analysis, the Family Support category stood out, as most of the responses indicated family members as the providers of assistance in care when needed $(44.1 \%)$. In this context, the daughters of the main caregiver (17.4\%), followed by the sisters $(12.8 \%)$ and the children $(8.13 \%)$ of caregivers were the most prevalent. As for the main caregiver's activities, bathing $(29.0 \%)$, food preparation $(19.7 \%)$ and accompanying the elderly person on visits to the doctor $(12.8 \%)$ were the most important.

Burden correlated negatively with age and schooling. Table 1 shows the data from the present study.

Table 1. Sociodemographic and care profile of caregivers of elderly persons registered with SCRC. São Carlos, São Paulo, 2016.

\begin{tabular}{|c|c|c|c|c|c|c|c|}
\hline Variable & $\mathrm{n}(\%)$ & Mean (sd) & [Min-Max] & $\begin{array}{l}\text { Absence of } \\
\text { burden }(\%)\end{array}$ & $\begin{array}{l}\text { Burden } \\
(\%)\end{array}$ & $\begin{array}{l}\text { Correlational } \\
\text { analysis }\end{array}$ & $p$-value \\
\hline \multicolumn{8}{|l|}{ Gender } \\
\hline Women & $62(71.7)$ & & & $18(21.0)$ & $44(50.7)$ & & \\
\hline Men & $24(27.9)$ & & & $3(3.5)$ & $21(24.4)$ & & \\
\hline Age (in years) & & $56.9(14.9)$ & $20-85$ & & & -0.11 & 0.922 \\
\hline \multicolumn{8}{|c|}{ Age group (years) } \\
\hline $20-39$ & $10(11.6)$ & & & $4(4.7)$ & $6(7.1)$ & & \\
\hline $40-49$ & $14(16.3)$ & & & $5(5.9)$ & $9(10.6)$ & & \\
\hline 50-59 & $16(18.6)$ & & & $5(5.9)$ & $11(12.9)$ & & \\
\hline $60-69$ & $27(31.4)$ & & & $7(8.2)$ & $20(23.5)$ & & \\
\hline 70-79 & $14(16.3)$ & & & $4(4.7)$ & $10(11.8)$ & & \\
\hline $80-89$ & $5(5.8)$ & & & $3(3.5)$ & $2(2.3)$ & & \\
\hline \multicolumn{8}{|l|}{ Marital status } \\
\hline With partner & $56(65.1)$ & & & $14(17.9)$ & $42(47.2)$ & & \\
\hline No partner & $30(34.8)$ & & & $7(5.1)$ & $19(29.7)$ & & \\
\hline
\end{tabular}


Continuation of Table 1

\begin{tabular}{|c|c|c|c|c|c|c|c|}
\hline Variable & $\mathrm{n}(\%)$ & Mean (sd) & [Min-Max] & $\begin{array}{l}\text { Absence of } \\
\text { burden }(\%)\end{array}$ & $\begin{array}{l}\text { Burden } \\
(\%)\end{array}$ & $\begin{array}{l}\text { Correlational } \\
\text { analysis }\end{array}$ & $p$-value \\
\hline Schooling (in years) & & $5.9(4.1)$ & $0-15$ & & & -0.87 & 0.425 \\
\hline Illiterate & $4(4.4)$ & & & 0 & $4(4.4)$ & & \\
\hline 1 to 4 & $74(85.9)$ & & & $54(62.7)$ & $20(23.2)$ & & \\
\hline 5 to 8 & $8(9.3)$ & & & $1(1.1)$ & $7(8.2)$ & & \\
\hline \multicolumn{8}{|l|}{ Current Occupation } \\
\hline Occupation & $29(33.7)$ & & & $13(15.1)$ & $16(18.6)$ & & \\
\hline No occupation & $4(4.7)$ & & & 0 & $4(4.7)$ & & \\
\hline Works at home & $53(61.6)$ & & & $15(17.4)$ & $38(44.2)$ & & \\
\hline \multicolumn{8}{|l|}{ Individual income } \\
\hline Not declared & $36(41.9)$ & & & $9(10.6)$ & $26(31.3)$ & & \\
\hline None & $4(4.7)$ & & & $4(4.7)$ & 0 & & \\
\hline Less than $1 \mathrm{MS}$ & $44(54.2)$ & & & $11(13)$ & $33(41.2)$ & & \\
\hline $1 \mathrm{MS}$ & $2(2.4)$ & & & 0 & $2(2.4)$ & & \\
\hline \multicolumn{8}{|l|}{ Income } \\
\hline Own salary & $13(15.1)$ & & & $8(9.3)$ & $5(5.8)$ & & \\
\hline Spouse's wage or pension & $18(20.9)$ & & & $6(7.0)$ & $12(14.0)$ & & \\
\hline Private or public pension & $37(43.0)$ & & & $12(14.0)$ & $25(29.1)$ & & \\
\hline Receives from children & $7(8.1)$ & & & $1(1.2)$ & $6(7.0)$ & & \\
\hline Benefit & $9(10.5)$ & & & 0 & $9(10.5)$ & & \\
\hline Citizen income & $2(2.3)$ & & & $14(16.3)$ & $21(24.4)$ & & \\
\hline \multicolumn{8}{|l|}{ Degree of kinship } \\
\hline Spouse & $35(40.7)$ & & & $14(16.3)$ & $21(24.4)$ & & \\
\hline Daughter & $34(39.5)$ & & & $8(9.3)$ & $26(30.2)$ & & \\
\hline Son & $6(7.0)$ & & & 0 & $6(7.0)$ & & \\
\hline Others & $11(12.8)$ & & & $6(7.0)$ & $5(5.8)$ & & \\
\hline \multicolumn{8}{|l|}{ Social vulnerability } \\
\hline High (SCRC I, II and III) & $34(39.6)$ & & & & & & \\
\hline Low (SCRC IV) & $15(17.4)$ & & & $12(14.0)$ & $22(25.6)$ & & \\
\hline Very low (SCRC V) & $37(43.1)$ & & & $9(10.5)$ & $6(7.0)$ & & \\
\hline Burden & & & & $7(8.1)$ & $30(34.9)$ & & \\
\hline No burden & $28(32.5)$ & & & & & & \\
\hline Burden & $58(67.4)$ & & & & & & \\
\hline \multicolumn{8}{|l|}{ Care activities } \\
\hline \multicolumn{8}{|l|}{ BADL } \\
\hline Feeding & $52(60.4)$ & & & & & & \\
\hline Bathing & $34(39.5)$ & & & & & & \\
\hline \multicolumn{8}{|l|}{ IADL } \\
\hline Housework & $44(51.1)$ & & & & & & \\
\hline Accompany to doctor & $44(51.1)$ & & & & & & \\
\hline
\end{tabular}


Continuation of Table 1

\begin{tabular}{lllllll}
\hline Variable & $\mathrm{n}(\%)$ & Mean $(\mathrm{sd})$ & {$[$ Min-Max $]$} & $\begin{array}{l}\text { Absence of } \\
\text { burden }(\%)\end{array}$ & $\begin{array}{l}\text { Burden } \\
(\%)\end{array}$ & $\begin{array}{l}\text { Correlational } \\
\text { analysis }\end{array}$
\end{tabular}

Limitations of care

Reported difficulty $\quad 56(20.9)$

Physical exertion $18(21.0)$

Reported no difficulty 30 (35.0)

Help with care

Reported receiving help $\quad 48$ (55.8)

Relatives $\quad 38$ (44.1)

Reported not receiving help 38 (44.1)

sd: standard-deviation; MS: minimum salary (R\$880); BADL: basic activities of daily living; IADL: instrumental activities of daily living; $p$-value $<0.05$

\section{DISCUSSION}

Data from the present study revealed that the majority of caregivers were women $(71.7 \%)$, while male caregivers made up $27.9 \%$ of the sample. There was a predominance of caregivers with some degree of kinship with the elderly, a mean age of $56.9(+14.9)$ years, schooling of one to four years and income of less than one minimum wage.

Literature indicates that care tends to be carried out by women, who tend to perform the role of mother and provide care for their relatives and in most cases are thereby assigned the responsibility of primary caregiver ${ }^{3}$. Caregivers are rarely men, as caring involves tasks considered to be feminine, which are learnt throughout life.

Schooling is an important indicator as a criterion for identifying the level of social vulnerability of a given region. Of the caregivers interviewed, the majority had low levels of schooling, which can affect the care provided to the elderly person. Schooling, being an indicator of vulnerability, contributes to the limitations of social and economic mobility of people as well as affecting levels of productivity and income, which can compromise caregivers when seeking information and resources in public systems ${ }^{10}$. Santos-Orlandi et al. ${ }^{17}$ emphasize that social vulnerability is one of the factors that contribute to a lack of individual, family and social resources to meet the needs of the people.
A minimum salary income or below, followed by a low level of education among caregivers, often results from the fact that caregivers have to leave their jobs to care for their relatives. Literature shows that low schooling can influence the performance of care activities, such as help with medication, accompanying patients to doctor's appointments, and the ability to receive and communicate medical guidance. From this perspective, the higher the level of schooling, the better the quality of care provided $^{18}$. In addition, Yamashita et al. ${ }^{5}$ found that a lack of income from an occupation outside the home leads caregivers to assume the leading role in providing care.

The data from this study showed that the income obtained is most commonly through a state or public pension followed by the salary of a spouse or partner. The low use of public resources by vulnerable populations is noteworthy, with low levels of income received through the Continuous Cash Benefit program (BPC) - granted to the elderly or to persons with disabilities who do not have sufficient means to support themselves - and Citizen Income Support - a state program for the transfer of income and financial support to families with a monthly per capita income of up to half the minimum wage ${ }^{19}$. This is worrying as elderly persons often become the main source of income of their family units in vulnerable sectors of the Brazilian population ${ }^{20}$. 
Most of the caregivers interviewed in this study had some degree of kinship with the elderly, with the proximity and affective relationship between the caregiver and the elderly person contributing to the process of insertion and adaptation of the caregiver in this role. When care is performed by a caregiver with a close family relationship the chances of negative feelings arising are lower. The negative effects on the caregiver when caring for a family member at home may not be as apparent, with many caregivers saying they did not experience difficulty in performing their roles, perhaps because of a sense of recognition of said role and the positive aspects of performing care ${ }^{21}$. Literature shows that caring for a loved one can be more meaningful and rewarding than the social difficulties generated in the caring process. On the other hand, care provided through obligation can result in burden and consequently make the process exhausting.

There was a high prevalence of caregivers with burden at all levels of social vulnerability in the present study. The overall mean burden of the family caregivers in the present study was similar to other studies with caregivers of elderly persons living in the community ${ }^{22-25}$. A systematic review found that family caregivers suffer burden due to performing several roles and exposure to multiple factors that lead to attrition. The lack of choice in becoming a caregiver was the most frequent feature in these studies, due to the difficulties families have in resolving the problem of care, which subsequently often falls to a single member ${ }^{26}$.

Social vulnerability can vary according to socioeconomic criteria of a given population and can be used as a synonym of social risk, frailty and precariousness ${ }^{27}$. Social factors that are related to the individual, such as educational level, family members, marital status, the influences of the neighborhood in which one lives, individual life histories, cultural differences and social position should also be considered $^{28}$. Vulnerability is therefore related to the structural factors of society in terms of inequality of income, education and access to services, and is a suitable concept for understanding the dynamics of the process of social inequality in developing countries $^{29}$. In this context, caregivers of the elderly in a context of vulnerability have specific needs arising from their socio-family characteristics, which are peculiar to this group.

Caregiver burden is an indicator of negative impact that can affect the physical, psychological, emotional and financial state and cause mental health outcomes ${ }^{30,31}$. Caregivers are often not ready to assume all the responsibilities thrust upon them without support. They are faced with unexpected situations and require suitable guidance to perform their tasks.

Elderly caregivers undergo constant changes due to the care they provide, with less time for leisure and social activities, which may worsen when the care is provided in a context of vulnerability and can cause depression, anxiety, dissatisfaction with life, the aggravation of illness and risk of disease ${ }^{17}$. Technical, psychological and financial support, guidance, working in groups and the accompanying and monitoring of these caregivers in the public system is required.

In this study caregivers helped the elderly with basic and instrumental activities of daily living. The independence of the elderly person is closely linked to their ability to perform daily activities without assistance, autonomy, freedom and decisionmaking capacity ${ }^{7}$. Although the aging process is not associated with the loss of independence and autonomy, literature indicates that functional capacity is an indicator of the health of the elderly population, when there may be a greater risk of limitations and needs for care. Functional incapacity indicates the risk of hospitalization and institutionalization among the elderly $y^{32}$. In the context of social vulnerability, the low levels of schooling and income of caregivers imply difficulties in the management of care and access to and obtaining specialized services.

Regarding the limitation of care, a portion of the caregivers interviewed in this study reported having difficulties in providing care. According to research, in order for home care to be performed effectively, the preparation of the caregiver is fundamental; processes of training and guidance should be provided by basic care services. Information on care should be disseminated and distributed to all stakeholders involved to guarantee the care provided at home ${ }^{33}$. 
In the present study, $55.8 \%$ of the caregivers reported that they received help from other relatives when performing care. In general, informal care is expected to be carried out by family members, with this characteristic influenced by cultural and religious norms ${ }^{34}$. In the context of vulnerability, low incomes limit support for care or ways of paying for this service. There is a need for policies and initiatives that support caregivers and which care for the elderly. As the health profiles of populations change, care systems need to be reassessed to ensure that they reach older people with more complex needs, as well as their caregivers. In this sense, identifications and interventions to eradicate, prevent or reverse burden must be included in SCRC strategies. These centers can prevent the breaking of links and promote autonomy and sociability in the family and community context, considering the heterogeneity of values, beliefs and identities through actions of a protective and proactive nature ${ }^{35}$. Social care teams need to familiarize themselves with the conditions of aging, optimize services and consider social support for the elderly, including care and long-term assistance, since these services have a broad scope and knowledge of the context in which they are inserted.

Studies in basic social protection services are suggested, as these are considered the gateway of users to the care system and are therefore the closest contact with the population and understand their specific needs and limitations. There is subsequently a need for the system to empower teams to monitor and support families. Literature still presents gaps regarding studies that verify the burden of

\section{REFERENCES}

1. Lana LD, Schneider RH. Síndrome de fragilidade no idoso: uma revisão narrativa. Rev Bras Geriatr Gerontol. 2014;17(3):673-80.

2. Loureiro LSN, Fernandes MGM, Lima da Nóbrega MM, Rodrigues RAP. Sobrecarga em cuidadores familiares de idosos: associação com características do idoso e demanda do cuidado. Rev Bras Enferm. 2014;67(2):227-32. caregivers of the elderly in different contexts of social vulnerability. As a limitation of the study, it should be highlighted that the cross-sectional design used does not allow causality to be established, and the sample size may limit the generalization of the results.

\section{CONCLUSION}

The present study demonstrates the existence of burden among caregivers and found that this phenomenon correlated negatively with age and schooling. The care needs were evidenced by means of thematic analysis, namely: assistance in basic and instrumental activities of daily life; existence of tensions and difficulties in the task of caring and help from family members in care activities.

The findings can contribute to the re-adaptation and redirection of public policies that provide formal support for family caregivers, with a view to integrating primary care services into actions for the execution of care. The results found draw the attention of public health administrators to the need to understand the profile and degree of burden and activities related to care, as the actors involved in the care process will become elderly in the medium term, which may lead to greater difficulty in providing care and consequently influence burden and have consequences for both the caregiver and the elderly. It is worth highlighting that investigations in a context of vulnerability allow the needs of the population to be identified in loco, as well as the understanding of determinants related to health, especially in those with multiple and interactive problems arising from their social context.
3. Nardi EDFR, Dos Santos LMR, De Oliveira MLF, Sawada NO. Dificuldades dos cuidadores familiares no cuidar de um idoso dependente no domicílio. Ciênc Cuid Saúde. 2012;11(1):98-105.

4. Silva CF, Azeredo Passos VM, Barreto SM. Frequência e repercussão da sobrecarga de cuidadoras familiares de idosos com demência. Rev Bras Geriatr Gerontol. 2012;15(4):707-31. 
5. Yamashita CH, Amendola F, Gaspar JC, Alvarenga MRM, Oliveira MAC. Associação entre o apoio social e o perfil de cuidadores familiares de pacientes com incapacidades e dependência. Rev Esc Enferm USP. 2013;47(6):1359-66.

6. Gratão ACM, Vendrúscolo TRP, Talmelli LFDS, Figueiredo LC, Santos JLF, Rodrigues RAP. Sobrecarga e desconforto emocional em cuidadores de idosos. Texto \& Contexto Enferm. 2012;21(2):304-12.

7. Brandão FSR, Souza BC, Rego ZC, Bezerra M, Alencar LCA, Leal MCC. Sobrecarga dos cuidadores idosos assistidos por um serviço de atenção domiciliar. Rev Enferm UFPE. 2017;11(1):272-9.

8. Olegário BB, Beuter M, Girardon-Perlini NMO, Brondani CM, Budó MDLD, dos Santos NO. A sobrecarga do familiar cuidador no âmbito domiciliar: uma revisão integrativa da literatura. Rev Gaúch Enferm. 2012;33(1):147-56.

9. Vidigal FC, Ferrari RFR, Rodrigues DMMR, Marcon SS, Baldissera VDA, Carreira L. Satisfação em cuidar de idosos com alzheimer: percepções dos cuidadores familiares. Cogitare Enferm. 2014;19(4):768-75.

10. Cruz SS, Sousa FQ, Oliveira CJ, Alves CAB, Souto JS, Nunes EN. Vulnerabilidade socioeconômica em comunidades rurais do município de Areia, Estado da Paraíba. Sci Plena. 2013;9(5):1-10.

11. Lino VTS, Rodrigues NCP, Camacho LAB, O’Dwyer G, Lima ISD, Andrade MKDN, et al. Prevalência de sobrecarga e respectivos fatores associados em cuidadores de idosos dependentes, em uma região pobre do Rio de Janeiro, Brasil. Cad Saúde Pública. 2016;32(6)1-14.

12. Fundação Sistema Educacional de Análise de Dados. Distribuição da população, segundo grupos do Índice Paulista de Vulnerabilidade Social (IPVS). São Paulo: IPVS; 2010.

13. Instituto Brasileiro de Geografia e Estatística. Indicadores sociais do município de São Carlos. 2013. [Sem Local]: IBGE; 2013.

14. Sequeira CAC. Adaptação e validação da Escala de Sobrecarga do Cuidador de Zarit. Rev Referência. 2010;12(2):9-16.

15. Minayo MCS. O Desafio do conhecimento: pesquisa qualitativa em saúde. 14ª ed. São Paulo: Hucitec; 2014.

16. Bardin L. Análise de conteúdo. São Paulo: Edições 70; 2010 .

17. Santos-Orlandi AAD, Brito TRPD, Ottaviani AC, Rossetti ES, Zazzetta MS, Gratão ACM, et al. Profile of older adults caring for other older adults in contexts of high social vulnerability. Esc Anna Nery. 2017;21(1):1-8.
18. Magalhães MJS, Silva AC. Conhecimento e dificuldades enfrentadas por cuidadores acerca de idosos acamados. Rev Enferm UFPI. 2014;3(1):32-8.

19. São Paulo (Estado). Secretaria Nacional de Assistência Social. Programa Renda Cidadã. São Paulo: Secretaria de Desenvolvimento Social; 2015.

20. Duarte MCS, Fernandes MDGM, Rodrigues RAP, Da Nóbrega MML. Fragilidade, morbidade referida e capacidade funcional em mulheres idosas. Rev Enferm UERJ. 2016;24(2):1-6.

21. Loureiro LSN, Fernandes MGM, Nóbrega MML, Rodrigues RAP. Sobrecarga de cuidadores de familiares idosos: prevalência e associação com características do idoso e do cuidador. Rev Esc Enferm USP. 2013:47(5):1133-40.

22. Bom FS, Sá SPC, Cardoso RSS. Overload in caregivers of the elderly. Rev Enferm UFPE on line. 2017;11(1):160-4.

23. Ballarin MLGS, Benedito AC, Krön CA, Christovam D. Sociodemographic profile and burden of informal caregivers of patients assisted in occupational therapy outpatient clinic. Cad Ter Ocup UFSCar. 2016;24(2):315-21.

24. Avelar Muniz E, Freitas CASL, Oliveira EN, Lacerda MR. Grau de sobrecarga dos cuidadores de idosos atendidos em domicílio pela Estratégia Saúde da Família. Saúde Debate. 2016;40(110):172-82.

25. Rodrigues JEG, Machado ALG, Vieira NFC, Fernandes AFC, Rebouças CBD. A qualidade de vida e sobrecarga de cuidadores familiares de idosos dependentes. Ciênc Enferm. 2014;20(3):119-29.

26. Baptista BO, Beuter M, Girardon-Perlini NMO, Brondani CM, Budó MLD, Santos NO. A sobrecarga do familiar cuidador no âmbito domiciliar: uma revisão integrativa da literatura. Rev Gaúcha Enferm. 2012;33(1):147-56.

27. Andrew MK, Keef J. Social vulnerability from a social ecology perspective: a cohort study of older adults from the National Population Health Survey of Canada. BMC Geriatr. 2014;14(1):1-18.

28. Browne-Yung K, Ziersh A, Baum F. Faking til you make it's: social capital accumulation of individuals on low incomes living in contrasting socio-economic neighborhoods and its implications for health and wellbeing. Soc Sci Med. 2013;85:9-17

29. Rinco M, Lopes A, Domingues MA. Envelhecimento e vulnerabilidade social: discussão conceitual à luz das políticas públicas e suporte social. Kairós. 2012;16(15):79-95. 
30. Trindade I, Almeida D, Romão M, Rocha S, Fernandes S, Varela V, et al. Caracterização do grau de sobrecarga dos cuidadores de utentes dependentes da Unidade de Saúde Familiar USF Descobertas. Rev Port Med Geral Fam. 2017;33(3):178-86.

31. Ringer T, Hazzan AA, Agarwal A, Mutsaers A, Papaioannou A. Relationship between family caregiver burden and physical frailty in older adults without dementia: a systematic review. Syst Rev. 2017;6(1):1-16.

32. Castro DC, Nunes DP, Pagotto V, Pereira LV, Bachion MM, Nakatani AYK. Incapacidade funcional para atividades básicas de vida diária de idosos: estudo populacional. Ciênc Cuid Saúde. 2016;15(1):109-17.
33. Ferreira PC, Bansi L, Paschoal SMP. Serviços de atenção ao idoso e estratégias de cuidados domiciliares e institucionais. Rev Bras Geriatr Gerontol. 2014;17(4):911-26.

34. Oliveira DC, Neri AL, D’Elboux MJ. Variáveis relacionadas à expectativa de suporte para o cuidado de idosos residentes na comunidade. Rev Latinoam Enferm. 2013;21(3):1-8.

35. Brasília. Ministério do Desenvolvimento Social e Combate à Fome; Secretaria Nacional de Assistência Social. Política Nacional de Assistência Social PNAS/ 2004. Norma Operacional Básica - NOB/ SUAS. Brasília, DF: 2004. 